\title{
Clinical practice improvement in the genetics clinic
}

\author{
S Greening
}

From Familial Aspects of Cancer 2011 Research and Practice: A combined meeting of kConFab, Australian Breast Cancer Family Study, Australian Colorectal Cancer Family Study, Australian Ovarian Cancer Study, Family Cancer Clinics of Australia and New Zealand and kConFab

Kingscliff, Australia. 23-26 August 2011

Quality in health is defined as 'doing the right thing, the first time, in the right way, and at the right time". A model for practical quality improvement in the genetic unit will be presented, along with tools and techniques relevant to the practice of clinical genetics, and examples from real life practice.

Clinical Improvement follows five phases, including:

- Project Phase; the process that needs improving is highlighted and defined, a team is formed, an aim or mission statement is produced, and a method of measurement is chosen.

- Diagnostic Phase: collect the evidence needed to diagnose the problem (its nature, its causes), and organise and prioritise the information using specific templates.

- Intervention Phase: involves using PDSA cycles to trial efficient methodologies and refine an implementation plan.

- Impact Phase: implement the changes, including implementation of a resistance management plan

- Sustaining Improvement phase; develop plans for standardisation, documentation, measurement, review and training/education of staff.

In addition, preparation of results for submission to area health Quality Awards is reviewed, and preparation of results for publication.

Published: 12 April 2012

doi:10.1186/1897-4287-10-S2-A44

Cite this article as: Greening: Clinical practice improvement in the

genetics clinic. Hereditary Cancer in Clinical Practice 2012 10(Suppl 2):A44.

Wollongong Hereditary Cancer Clinic, Australia
Submit your next manuscript to BioMed Central and take full advantage of:

- Convenient online submission

- Thorough peer review

- No space constraints or color figure charges

- Immediate publication on acceptance

- Inclusion in PubMed, CAS, Scopus and Google Scholar

- Research which is freely available for redistribution

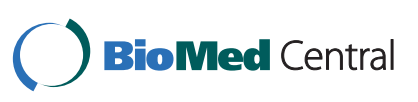

(c) 2012 Greening; licensee BioMed Central Ltd. This is an Open Access article distributed under the terms of the Creative Commons Attribution License (http://creativecommons.org/licenses/by/2.0), which permits unrestricted use, distribution, and reproduction in any medium, provided the original work is properly cited. 